\title{
The credit crunch, interrelations between (in)stability of housing markets and the general economy: setting the scene
}

\author{
Hugo Priemus • Duncan Maclennan
}

Published online: 14 June 2011

(C) Springer Science+Business Media B.V. 2011

\section{Introduction}

The most important development determining current housing-market and housing policies worldwide is the credit crunch. When the problems exploded on US mortgage markets, a banking crisis started in the US and later in other parts of the world. From a scientific viewpoint there is insufficient knowledge about the relation between an economic crisis (in particular a credit crunch) and national housing systems.

This special issue seeks to connect a general analysis of the current credit crunch, the way it manifests itself in one country or several, and the policies to fight it. Thus, the economic crisis will be related to the characteristics of the national housing systems and specific policies to stimulate housing demand and construction. The main objective of this issue is to identify which institutions, policies and characteristics determine the resilience of housing systems and then to suggest how the resilience of these systems could be improved.

The analysis covers not only the impact of the credit crunch on the housing system but also the impact that shocks in the housing system have on the general economic situation.

This theme was addressed during the ISA-RC43 conference in Glasgow (September $1-4,2009)$ in a number of papers and keynote presentations. These formed the starting point for this special issue.

\section{Aftermath of financial crises: general findings}

Reinhart and Rogoff (2008a, b, 2009) have carried out detailed analyses of systemic banking crises and identified around twenty serious ones since the end of WW II. They

\footnotetext{
H. Priemus

OTB Research Institute for the Built Environment, Delft University of Technology,

Delft, The Netherlands

e-mail: h.priemus@tudelft.nl

D. Maclennan $(\bowtie)$

Centre for Housing Research, University of St Andrews, St Andrews, UK

e-mail:dm103@st-andrews.ac.uk
} 
closely analyzed the antecedents and aftermath of financial crises in advanced economies (USA 1929, Spain 1977, Norway 1987, Sweden 1991, Finland 1991 and Japan 1992) and countries in transition (Malaysia 1997, Indonesia 1997, Thailand 1997, the Philippines 1997, Hong Kong 1997, Korea 1997, Colombia 1998 and Argentina 2001) (CPB 2009). Their analysis revealed broadly similar patterns in house and equity prices, unemployment, and government revenue and debt in mature and emerging markets. The study of the aftermath of severe financial crises focused on 19 post-war cases and two pre-war cases.

Reinhart and Rogoff (2009) concluded that the aftermath of severe financial crises is usually characterized by three developments:

"First, asset market collapses are deep and prolonged. The real housing price declines by an average of $35 \%$ stretched out over 6 years, while equity price collapses by an average of $55 \%$ over a downturn of about three and a half years. Second, the aftermath of banking crises is associated with profound declines in output and employment. The unemployment rate rises by an average of $7 \%$ points over the down phase of the cycle, which lasts on average for 4 years. Output (measured in Gross Domestic Product; HP \& DM) falls (from peak to trough) by an average of over $9 \%$, although the duration of the downturn, averaging roughly 2 years, is considerably shorter than for unemployment. Third, the real value of government debt tends to explode, rising by an average of $86 \%$ in the major post-World War II episodes. Interestingly, the main cause of debt explosions is not the widely cited costs of bailing out and recapitalizing the banking system" (...) "In fact, the big drivers of debt increases are the inevitable collapse in tax revenues that governments suffer in the wake of deep and prolonged output contractions, as well as often ambitious countercyclical fiscal policies aimed at mitigating the downturn".

The IMF (2009a: 125) gives an overview of economic indicators around peaks of current and previous recessions (Fig. 1), which illustrates the findings of Reinhart and Rogoff (2009).

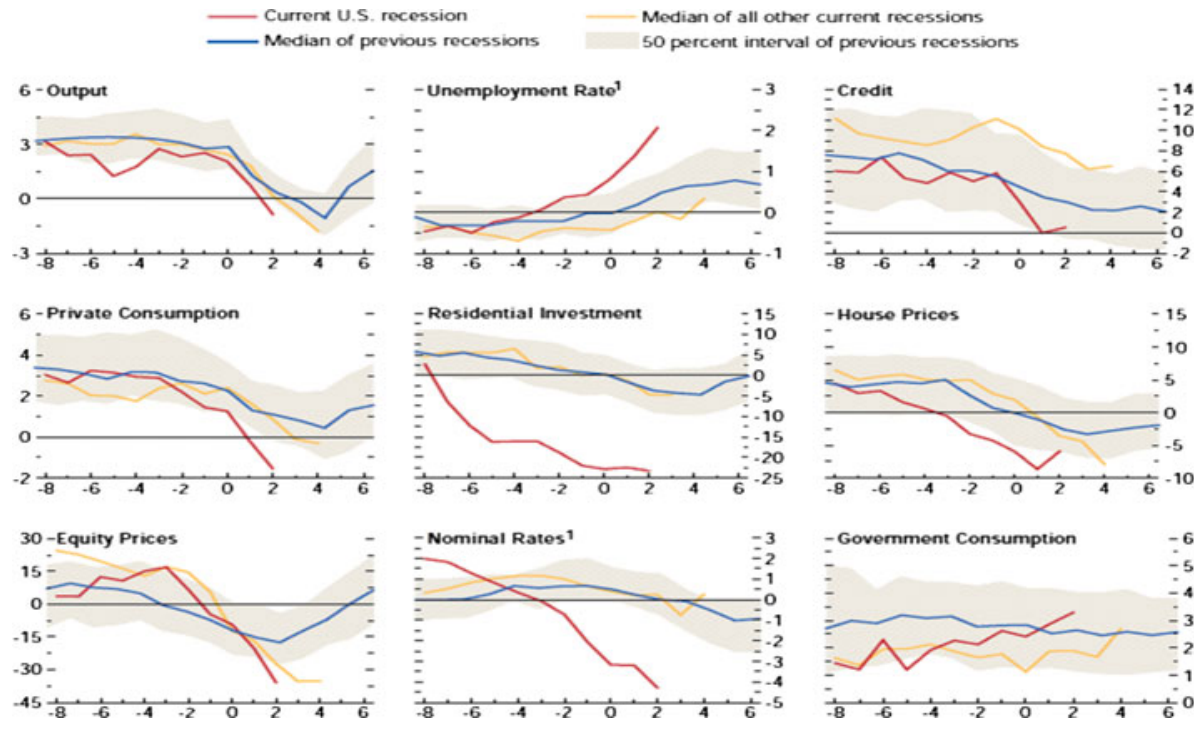

Fig. 1 Economic indicators around peaks of current and previous recessions (median log differences from 1 year earlier unless otherwise noted; peak in output at $\mathrm{t}=0$; data in real terms unless otherwise noted; quarters on the $x$-axis). ${ }^{1}$ Median percentage point difference from 1 year earlier. Source: International Monetary Fund (IMF) 2009a: 125 


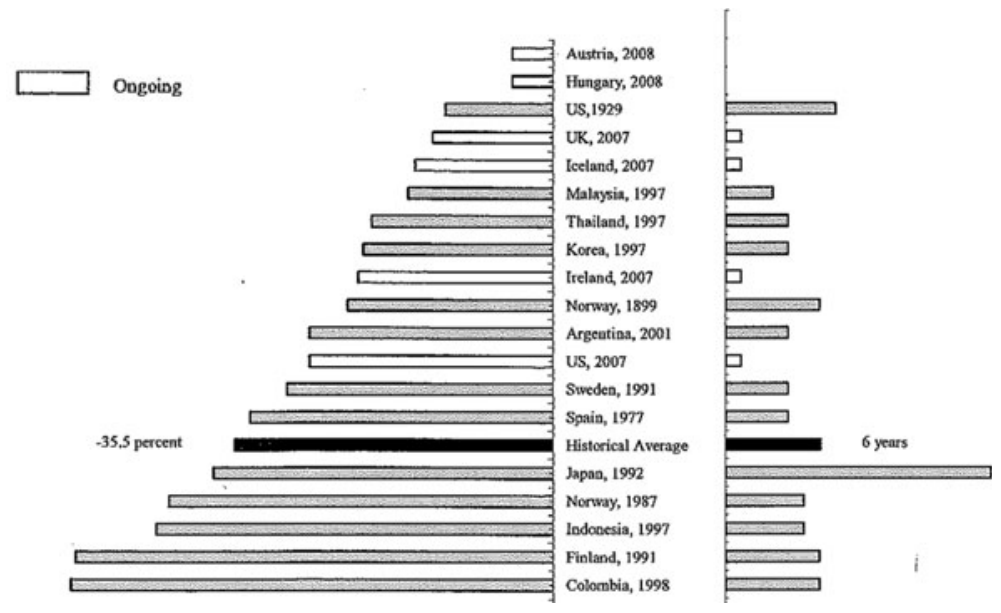

Fig. 2 Past and ongoing real house price cycles and banking crises: peak-to-trough price declines (left panel) and years duration of downturn (right panel). Each banking crisis episode is identified by country and the start year of the crisis. Only major (systemic) banking crises are included, subject to data limitations. The reported historical average does not include ongoing episodes of crisis. Consumer indices are used to deflate nominal house prices. Source: Reinhart and Rogoff (2009)

Figure 2 shows the decline in real house prices and the duration of the downturn in two pre-war and 19 post-war crises, sorted out by Reinhart and Rogoff (2009).

Some of the countries in Fig. 2 (Austria, Hungary, Iceland, Ireland, Spain, the United Kingdom and the USA) are still in the throes of a banking crisis. Ongoing crises are in dark shading and past crises are in light shading. The historical average (colored black in the diagram) does not include the ongoing crises.

Reinhart and Rogoff (2009) found that the cumulative decline in real housing prices from peak to trough averages $35.5 \%$. The most severe real housing price declines were experienced by Finland, the Philippines, Colombia and Hong Kong with crashes of $50-60 \%$, measured from peak to trough. The housing price decline experienced by the United States to date during the current episode (almost 28\% according to the Case-Shiller index) is already more than twice that registered in the US during the Great Depression.

Notably, the duration of housing price declines is quite long-lived, averaging roughly 6 years. Even excluding the extraordinary experience of Japan (with its 17 consecutive years of price declines since 1992), the average is still over 5 years. Reinhart and Rogoff (2009) observe that falls in the stock market are sharper and shorter-lived than falls in the house prices.

Rogoff and Reinhart (2009) describe the mounting national debt as a defining characteristic of the aftermath of banking crises. They conclude that, so far, the current crisis in the US has followed the pattern of history. The historical facts paint a "sobering picture" of the way the current economic crisis will unfold in the coming years. Apparently, it still has a long way to go.

The International Monetary Fund (IMF) (2009a) confirms the findings of Reinhart and Rogoff and concludes that banking problems have a deeper impact on general economic crises than other causes. In addition, it concludes that economic crises are most severe when they are highly synchronized, i.e. when they take place in many countries simultaneously (International Monetary Fund (IMF) 2009a: 113-114). The current economic crisis follows both definitions and, as a matter of fact, belongs to the most severe category identified by the International Monetary Fund (IMF) (2009a) (Figs. 3, 4). 


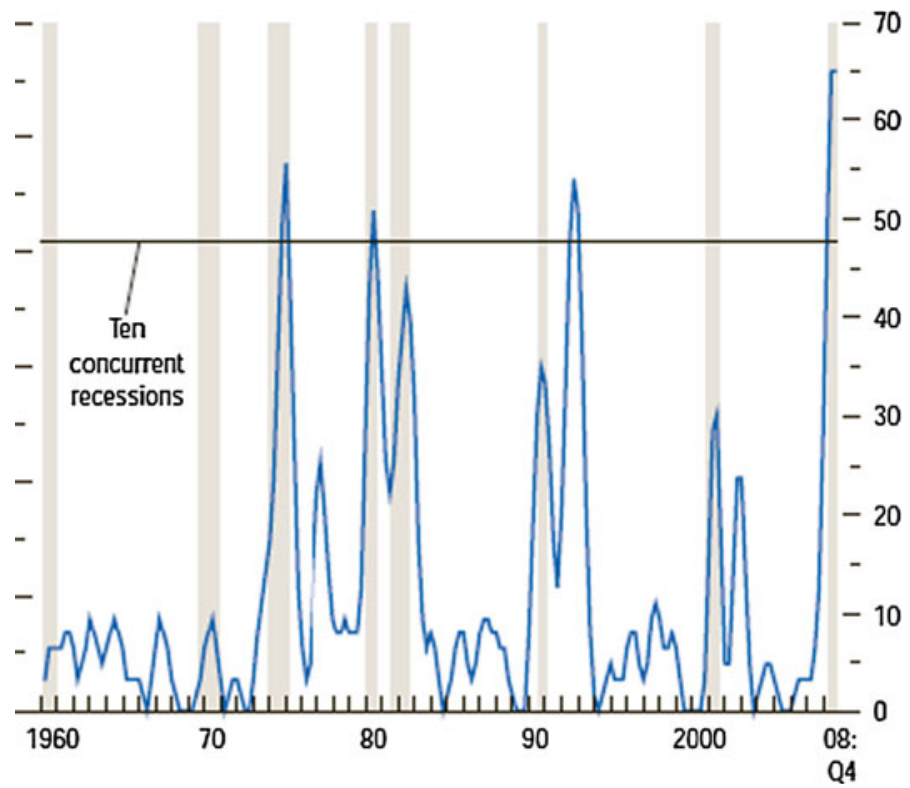

Fig. 3 Highly synchronized recessions (percent of countries in recession; shaded areas denote US recession). Source: International Monetary Fund (IMF) 2009a: 113

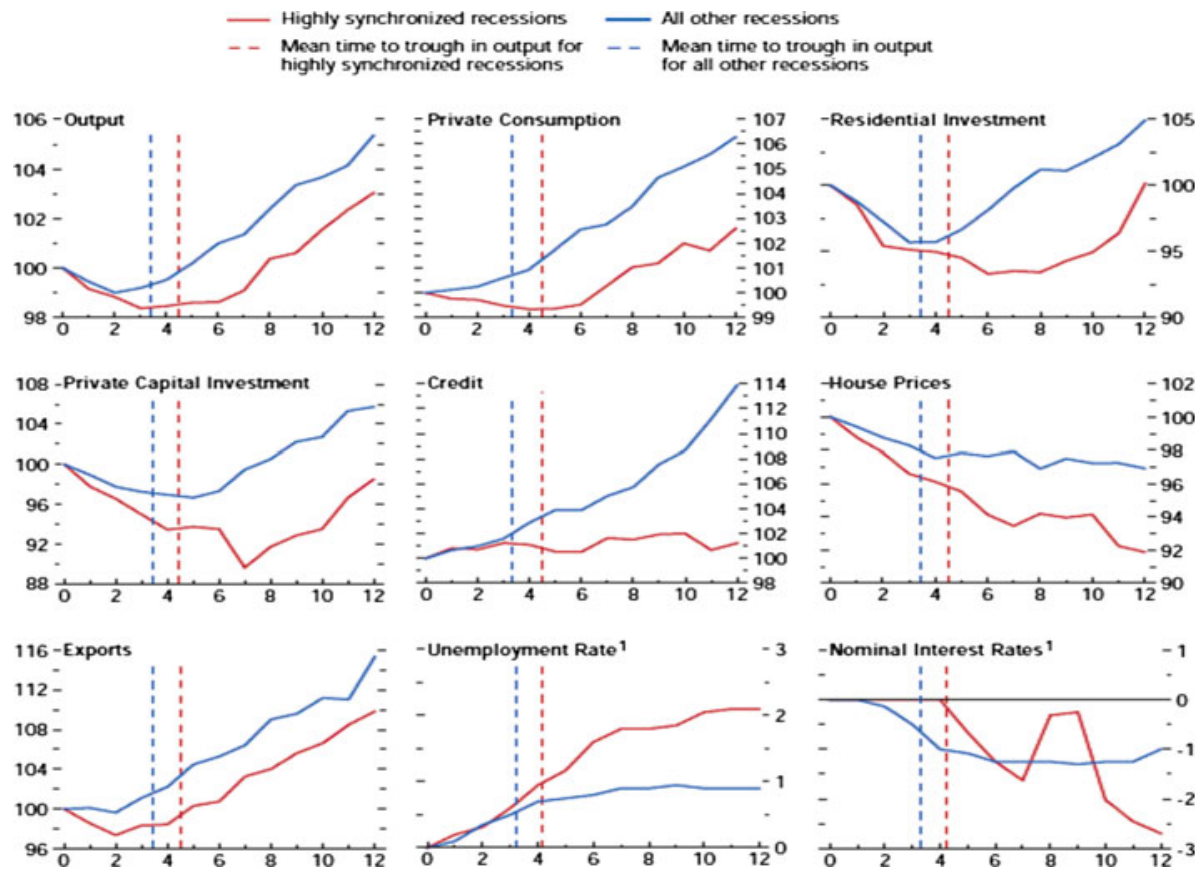

Fig. 4 Highly synchronized recessions are different (median $=100$ at $\mathrm{t}=0$; peak in output at $\mathrm{t}=0$; data in real terms unless otherwise noted; quarters on the $x$-axis). Source: International Monetary Fund (IMF) 2009a: 114 
The analysis by Reinhart and Rogoff (2008a, b, 2009) and the IMF study (2009a, b) can serve as a template for interpreting the impact of the banking crisis on national housing markets.

\section{Impacts on housing markets}

The impacts of the global credit crunch on the housing market have been many and various. The mortgage market has been particularly hard hit. The international banks financed asset-backed securities that were much lower in value than was initially assumed and mortgage assessments by rating agencies were far too optimistic in innumerable cases. Now the banks view one another with deep distrust and have set new requirements for mortgage providers. As a result, getting a mortgage has become much more difficult and expensive for prospective home-owners.

The financial crisis is leading to economic stagnation and hampering mobility on both the labor market and the housing market. The demand for housing is stagnating, particularly at the high end of the market.

National governments had no choice but to bail out the banks since a dysfunctional banking system would have spelled economic disaster. Later, the same governments were more or less forced to cut public spending, not only to finance the billion-euro bail-out but also to offset lower tax revenues and the mounting costs of state benefits.

The sharp fall in the demand for housing has created serious problems for construction firms, architects and real estate agents. The revaluation of many land parcels that were designated for housing will undermine the financial resilience of developers and make deep inroads in some municipal budgets.

The knock-on effect is manifesting itself in different ways, with some countries being harder hit than others. The more international the banking system, the greater the chance of financial bombshells. Some housing systems appear to be made of sterner stuff than others: a vibrant, differentiated rented sector is more resilient to blows. The risk of damage is greater in regions where house prices rose sharply and where speculation on the housing market was rife.

Some types of mortgage (variable interest, interest-only mortgages, teaser rates, subprime mortgages, high LTV, no deposit) have suffered more from the credit crunch than others.

This special issue reports and discusses some of the similarities and differences in the relationship between housing systems and the credit crunch.

\section{Overview of contributions}

This special issue of the Journal of Housing and the Built Environment is structured along the following lines. After this introductory editorial, Dan Immergluck (USA) examines the origins of the US subprime crisis, which first reached a national scale in early 2007 but started banking problems worldwide. Those banking problems had negative impacts on national housing markets in different parts of the world. Immergluck describes the shift during the latter decades of the twentieth century of the US mortgage market from a risklimited market to a risk-loving one. Proposals made since late 2008 to increase regulation of the US mortgage market are presented, including the evolution of those proposals towards actual legislation. 
Geoffrey Meen (UK) explains that the credit crunch was preceded by a strong build-up of mortgage debt internationally. This finding suggests that a credit crunch is more likely to recur because highly indebted households have weaker buffers to withstand unexpected shocks to their incomes or to interest rates. Meen presents a model that can explain the debt build-up and changes to the distribution of debt between existing owners and first-time buyers.

Kathleen Scanlon and Christine Whitehead (both UK) show how the UK mortgage market has responded to volatility. Lenders were reliant on the money markets and securitization in the boom period before 2007. This made the mortgage system vulnerable to the credit and financial crisis of 2007-2008. Other features have helped the system to weather the crisis: the low rate of transactions and the prevalence of variable rates and tracker mortgages. A negative consequence has been that first-time buyers experience more difficulties in obtaining mortgage funding.

Harry van der Heijden, Kees Dol (both NL) and Michael Oxley (UK) compare the way the international financial crisis has affected the national housing system in Ireland, England, the Netherlands, Belgium and Germany. The authors make a distinction between dynamic (UK, Ireland, the Netherlands) and static (Belgium, Germany) housing systems. The financial crisis appeared to have a deeper impact on dynamic than on static housing systems.

József Hegedüs (Hungary), Martin Lux and Petr Sunega (both Czech Republic) compare the impact of the global economic crisis on housing markets in two post-socialist states: Hungary and the Czech Republic. In Hungary there was a mild decline of markets, while in the Czech Republic there has been a depression of markets. Although postsocialist states have moved towards a market-based housing system, there are still substantial differences between countries. Divergence in national housing systems explains some of the differences in the impact of the global economic crisis on the housing and mortgage markets.

In an institutional analysis, Laurence Murphy (New Zealand) compares the impact of the global financial crisis on two housing systems in another part of the world: Australia and New Zealand. As a result of nationally constituted housing markets, activities of local financial institutions and national housing policies, the impacts of the global financial crisis may be different. Both Australia and New Zealand escaped a severe housing downturn. The housing systems in these countries sheltered the national markets but created the conditions for a potential new housing boom.

Alex Schwartz (USA) is the only contributor to this special issue who deals with the subsidized rented sector and not so much with the mortgage and owner-occupied markets. He compares the impact of the global financial crisis on the subsidized rented sector in the UK and the USA, which approach the housing needs of low-income households in different ways and to different degrees. The USA adopted a single program: the Low Income Housing Tax Credit. In the UK housing associations and housing benefits are the crucial instruments. The UK responded sooner and more effectively than the US to the crisis. Schwartz argues that the future prospects for affordable housing development are likely to be more difficult in the UK than in the USA.

Finally, Duncan Maclennan and Anthony O'Sullivan offer an overview of 'The global financial crisis: challenges for housing research and policies'. They review the findings of the contributions to this special issue, announce new perspectives on national housing policies and point out some new challenges for housing research in the coming years. 


\section{References}

Centraal Planbureau (CPB) (2009). Centraal economisch plan 2009 [Central economic plan 2009]. The Hague (CPB).

International Monetary Fund (IMF) (2009a). World economic outlook. Crisis and recovery. Washington DC (IMF), April.

International Monetary Fund (IMF) (2009b). World economic outlook. Update. Washington DC (IMF), July. Reinhart, C. M., \& Rogoff, K. S. (2008a). This time is different: A panoramic view of eight centuries of financial crisis. National Bureau of Economic Research Working Paper 12882, Cambridge (Mass.) (NBER), March.

Reinhart, C. M., \& Rogoff, K. S. (2008b). Banking crises: An equal opportunity menace. National Bureau of Economic Research Working Paper 14587, Cambridge (Mass.) (NBER).

Reinhart, C. M., \& Rogoff, K. S. (2009). The aftermath of financial crises. Paper presented at American Economic Associations meeting in San Francisco, College Park (Maryland) and Cambridge (Mass.), January 3 . 